\title{
meXicana Fashions
}

Politics, Self-Adornment, and Identity Construction

EDITED BY AÍDA HURTADO AND NORMA E. CANTÚ

University of Texas Press $\mathbf{v}$ Austin 
Copyright (c) 2020 by the University of Texas Press

All rights reserved

Printed in the United States of America

First edition, 2020

Chapter 9 originally appeared in Laura E. Perez, Eros Ideologies: Writings on Art, Spirituality, and the Decolonial (Duke University Press, 2019); (c Duke University Press; used by permission.

Requests for permission to reproduce material from this work should be sent to:

Permissions

University of Texas Press

P.O. Box 7819

Austin, TX 78713-7819

utpress.utexas.edu/rp-form

( ) The paper used in this book meets the minimum requirements of ANSI/NISO Z39.48-1992 (R1997) (Permanence of Paper).

\section{Library of Congress Cataloging-in-Publication Data}

Names: Hurtado, Aída, editor. | Cantú, Norma E., 1947- editor.

Title: MeXicana fashions : politics, self-adornment, and identity construction / edited by Aída Hurtado and Norma E. Cantú.

Description: First edition. | Austin : University of Texas Press, 2020. |

Includes bibliographical references and index.

Identifiers: LCCN 2019010289 | ISBN 978-1-4773-1958-1 (cloth : alk. paper) | ISBN 978-1-4773-1959-8 (pbk. : alk. paper) | ISBN 978-1-4773-1960-4 (library e-book) | ISBN 978-1-4773-1961-1 (nonlibrary e-book)

Subjects: LCSH: Mexican American women - Clothing. | Mexican American womenEthnic identity. | Clothing and dress-Political aspects - United States. | Clothing and dress - Social aspects - United States. | Fashion-Social aspects-United States. | Group identity-United States.

Classification: LCC E184.M5 M534 2020 | DDC 305.48/86872073-dc23

LC record available at https://lccn.loc.gov/2019010289

doi:10.7560/319581 